\title{
The FMEA Approach to Identification of Critical Failure Factors in ERP Implementation
}

\author{
Hadi Shirouyehzad (Corresponding author) \\ Department of Industrial Engineering, NajafabadBranches, Islamic Azad University, Isfahan, Iran \\ Postal Code: 81399-66387, Navid Al., Omid St., Khanehesfahan St., Isfahan, Iran \\ Tel: 98-331-229-1111Ｅ-mail: Hadi.shirouyehzad@gmail.com \\ Reza Dabestani \\ Department of Management, University of Isfahan, Isfahan, Iran \\ \#24, ShaghayeghSharghi Block, KowsarResidentialComplex, 5th alley, Golestan St. \\ Kaveh Ave. Postal code: 81939-55796, Isfahan, Iran \\ Tel: 98-913-303-5843Ｅ-mail: reza.dabestani@gmail.com \\ Mostafa Badakhshian \\ Faculty of Engineering, Universiti Putra Malaysia, Selangor, DE, 43400, Malaysia \\ \#24, ShaghayeghSharghi Block, KowsarResidentialComplex, 5th alley, Golestan St. \\ Kaveh Ave., Isfahan, Iran \\ Tel: 98-913-303-5843Ｅ-mail: m.badakhshian@gmail.com
}

Received: February 5, 2011 Accepted: February 26, 2011 doi:10.5539/ibr.v4n3p254

\begin{abstract}
Enterprise resource planning implementation has been one of challenges of organizations during the last decade; and there have been many barriers in implementing ERP successfully. Organizations can reduce the effect of failure through identifying their strengths and weaknesses. One of the most applicable methods which may prevent occurring defects in organizations is failure mode and effect analysis (FMEA). FMEA has been used for many applications as a quality management instrument. In FMEA, risks of failure modes are identified through the estimation of severity and occurrence values. In this paper, the proposed FMEA identifies major failure causes and effect of potential defects in ERP implementation. Furthermore, critical failure factors are characterized by the severity, occurrence and detection values by using the adopted FMEA table. A case study is also presented to prove the applicability of the proposed method.
\end{abstract}

Keywords: Risk Analysis, Failure Mode and Effect Analysis (FMEA), Enterprise Resource Planning (ERP), Critical Failure Factors (CFF), Implementation

\section{Introduction}

Enterprise resource planning (ERP) was started to be used in 1960s as a Material Requirements Planning (MRP), and an outcome of early efforts in bill of material processing. Crisostome (2008) described ERP as a system which consist of several integrated module that share data in organization in order to provide connectivity. The ERP system has been proved to be able to provide significant improvements in efficiency, productivity and service quality, and to lead to a reduction in service costs as well as to make decisions more effective (Ngai et. al., 2008). Wagner and Newell (2006) explain ERP as establishing a powerful business system, infrastructure for organizations providing "a depth of information by function and also a breadth of information horizontally across the value chain". The importance of ERP systems to an organization's competitiveness and the magnitude of ERP expenditures related to the firm resources imply that executives who implement these systems and academics studying ERP need to recognize which factors are likely to improve the chances of successful implementation. This study seeks to examine those critical failure factors leading to ERP success.

Risk analysis is an appropriate approach for distinguishing and evaluating the critical failure factors (CFF). Risk identification produces lists of project-specific and risk items that are likely to compromise a project failure. Risk 
analysis assesses the loss in probability and magnitude for each identified risk item. Risk prioritization produces a ranked ordering of risk items that are identified and analyzed. Aloini et al. (2007) collected and analyzed a number of key risk factors and their impact on ERP project success. They classified each risk factor and its relevance during the stages of the ERP project life cycle. Huang et al. (2004) used a Delphi method to identify potential ERP projects risk factors, and constructed an AHP-based framework to analyze and also prioritize the ERP projects risk factors.

One of the methods which can identify and prioritize CFF is failure mode and effect analysis (FMEA). FMEA is a design technique which systematically identifies and investigates potential system (product or process) weaknesses. It consists of a methodology for examining all the ways in which a system failure can occur, potential effect(s) of failures on system performance and safety, and the seriousness of these effects (Segismundo and Miguel, 2008). As the last considered point in failure investigation, the FMEA is devoted to determine design reliability by considering potential causes of failure and their effects on the system under study. The goal of FMEA is to prevent unacceptable failures from reaching the customer and to assist management in a more efficient allocation of resources. FMEA is used within a company risk management program to prevent customers from being subjected to unacceptable faults and to avoid customer dissatisfaction (Zafiropoulos and Dialynas, 2005).

An appropriate application of FMEA may lead to some advantages such as higher product reliability, less design modification, better quality planning, continuous improvement in product and process design, and lower manufacturing cost, in addition to meet customer requirements. FMEA is usually carried out by a team of people with direct knowledge of the procedures or processes concerned. The elements of FMEA are: identifying and listing the modes of failure and the consequent faults; assessing the chances that these faults occur; assessing the chances that faults can be detected; assessing the severity of the consequences of the faults; calculating a measure of the risk; ranking the faults on the basis of the risk; taking action on the high-risk problems; checking the effectiveness of the action, and using a revised measure of risk. The objective of FMEA is to prevent unacceptable failures and to assist management in a more efficient allocation of resources (Ahsen, 2008).

Over the previous decades many organizations have made significant investments in Enterprise-wide Systems, particularly Enterprise Resource Planning (ERP). While in most cases implementation is pretty successful, a considerable number of them have failed to achieve the expected objectives. Research studies have identified factors which influence the success of ERP implementations. Al-Mashari (2002) proposed taxonomy of ERP research including 24 items based on the previous studies. In this study, critical success/failure factors were addressed as one of the main aspects of ERP researches. Kim et al. (2005) addressed 47 impediments from previous ERP implementation studies. Their findings revealed that inadequate support from functional units, project management, and change management are the critical factors which large organizations face in the ERP systems implementation.

In another study by Koh et al. (2006) ERP adoption in Greek companies were examined based on a developed taxonomy of ERP adoption. The right/type of system, business and enterprise, system implementation and customization, business process reengineering, people management, change management, project management and risk management were considered as the critical failure/success factors in ERP adoption framework. Te findings proved that there were major differences between ERP adoption in Greek organization and other organization in USA and UK. In a study conducted by Crisostomo (2008) some factors which influence ERP successful implementation in public sector were addressed. The factors are as follows: (a) a knowledgeable and skillful project team which is able to manage the change process of the ERP project. (b) Defining the project scope clearly (c) employee's perception from the supports provided by project team and (d) confident end users.

In this paper, critical failure factors are examined using FMEA approach. A comprehensive framework which encompasses all the aspect of ERP implementation is used. The FMEA approach is used to identify, prioritize, and address the main potential failure effect, potential failure causes and control factors which influence successful implementation of ERP. Thus, this research is performed in a manufacturing company. Therefore, in the following, risk factors in ERP implementation are scrutinized separately into two levels. After that, FMEA model for ERP implementation is presented and the application of the proposed model is examined. Finally, the results are analysed, discussed and major conclusions are presented.

\section{Risk Factors in ERP Implementation}

A lot of CFF have been stated in the literatures but there is no framework or outline to prevent the problems occurring in the organization and also to provide system's requirements before ERP implementation. The organizations can reduce or obviate the effect of failure by the identifying their strengths and weaknesses. The critical failure factors in ERP implementation are as follows:

\subsection{Organization Fit}

A successful implementation of ERP is closely related to the condition of organization. Thus, ERP requirement 
should be compatible with organization characteristics.

\subsection{ERP Teamwork and Skill Mix}

An ERP project involves all of the functional departments in an enterprise. It demands the effort and cooperation of technical and business experts as well as end-users. Therefore, teamwork and team composition play a vital role in ERP implementation. The ERP team should be balanced, or cross-functioned, and comprise a mixture of external consultants and internal staff so the internal staff can develop the necessary technical skills for design and implementation. Further, members of project team(s) must be empowered to make quick decisions. Partnerships should be managed with regularly scheduled meetings. Incentives and risk-sharing agreements will aid in working together to achieve common goals (Wee, 2000).

It is also necessary to form a skill-balanced project team having both internal and external experts, managerial competencies, deep knowledge of the processes, and IT skills. The project team's business and technological competence will contribute to the ERP's implementation success or failure. Skills and knowledge of the project team are important in providing expertise in areas in which team members lack knowledge (Barki et al., 1993).

\subsection{Project Management}

Poor project management may cause failure in ERP implementation. An individual or group of people should be given responsibility to drive success in project management. Any proposed changes should be also evaluated against business benefits and, insofar as possible, implemented at a later phase (Sumner, 1999).

\subsection{Software System Design}

Development and testing perspectives unique to ERP projects must be well-thought-out and managed. The overall ERP architecture should be established before deployment, taking into account the most important requirements of the implementation. This prevents reconfiguration at every stage of implementation (Wee, 2000). Murray and Coffin (2001) and Scheer and Habermann (2000) indicated that the use of appropriate modeling methods, architecture, and tools will aid in achieving ERP success. Requirements definition can be created and system requirements definition can be documented.

\subsection{User Involvement and Training}

User involvement is important in meeting expectations. Key users should be convinced of the system utility; moreover they must be confident and expert so that they can aid future users in training sessions. User commitment and a "project champion" are useful in the early stages of the project and during the implementation phase. The role of training to facilitate software implementation is well documented (Nelson and Cheney, 1987). Computer-based training via Intranets has been also found to facilitate ERP implementations (Mahapatra and Lai, 1998).

\subsection{Technology Planning}

Technology planning is a critical factor in any organization. The mentioned factor can help organizations in ERP implementation through establishing a suitable infrastructure. Technology planning should be also considered in organizations in order to invest on new technologies and also to stable the current technology.

\subsection{Communication}

Expectations or goals at every level need to be communicated (Wee, 2000). Goals and expectations help organizations recognize milestones in ERP implementation. Communication should be complete and open to ensure honesty. Users need to know that the feedback they offer regarding the processes and problems with ERP will be received and acted upon. Complete and open communication can leverage success and facilitate enterprise-wide learning.

\subsection{Information Technology \&Legacy System}

ERP systems require people to work within the system and not around it (Umble et al., 2003); so old information systems should be removed. The transition phase is a critical period. Hence, information technology must be studied before implementation matters and their impact on business processes assessed; questions such as these are pivotal for ERP success. Technical aspects that are essential are: all necessary functionality, user friendliness, portability, scalability, modularity, versioning management, simple upgradeability, flexibility, security, presence of a complete guide, a procedure manual to help users, and data accuracy. Performances ERP systems require continuous investment in new modules and upgrades to add functionality, achieve a better fit between business and system, etc.

\subsection{Change Management}

Recognizing the need for change is very important. The stronger the need for change, the more likely top management and stakeholders support the ERP implementation. Enterprise-wide culture and structure change should 
be managed which includes people, organization, and culture change. A culture with shared values and a strong corporate identity that is conducive to change is critical. User involvement in the design and implementation of new business processes and the ERP system is recommended and formal education and training should be provided to help users understand how the ERP system impacts their jobs (Bingi et al., 1999; Shanks et al. 2000). In reality, training and education are usually some of the first items on a budget to be cut when a project overruns the allotted budget (Murray and Coffin, 2001).

\section{$2.10 B P R$}

In the process of configuring the ERP system, a large amount of reengineering should occur frequently to take advantage of the best practices offered by the system. Enterprises should be willing to accept the embedded best practice, whenever possible, and model their business processes according to those depicted by the system. Wee (2000) noted that, once the system is in use, reengineering should continue with new ideas and updates to take full advantage of the ERP system.

\subsection{Top Management Support}

Top management support is identified by many researchers as a success key factor in ERP implementation. Top management needs to publicly and explicitly identify the project as a top priority (Shanks et al. 2000;). Senior management must be committed with their own involvement and willingness to allocate valuable resources to the implementation effort (Shanks et al. 2000). This involves providing not only an appropriate amount of time and resources to get the job done, but also the necessary personnel for the implementation (Nah et al. 2003).

\subsection{Financial Support}

Although ERP system suppliers have increased their focus on SMEs, current systems are still expensive. Chen (2001) stated that economic and financial strategic justifications for an ERP project prior to installation were also necessary, because a wrong global costs analysis might impact the ERP adoption, cause the failure of system implementation projects or also bankruptcy.

The CFFs have been categorized by literature. In this paper the authors attempt to gather the most important factors in order to prioritize the CFFs through the FMEA approach. Table 1 presents these critical factors in two levels. The first level is referred to the requirements which should be prepared in ERP implementation projects, while the second level is related to the reasons which may cause to failure mode in details.

\section{FMEA Model for ERP Implementation}

Classical FMEA model is modified in order to prioritize the CFF in ERP implementation. The critical failure factors stated in the previous part are considered being the potential failure causes in FMEA approach. Five steps of proposed approach are as follows:

\section{Step 1- Potential Failure Modes Specification}

Failure mode is the inability of a component, subsystem, system or process whereas it may potentially cause to failure in implementation phase. The potential failure modes in ERP implementation are the factors which obstruct ERP implementation successfully as explained in a project. The potential failure mode is depicted in the part one of Table 2 .

\section{Step2-Potential Failure Effects Specification}

A potential effect of the failure is the consequence of a system failure mode. The question usually asked is: "what happened or what is (are) the ramification(s) of this problem or failure?" Often the failure effect is evaluated by severity from one to ten (Davenport, 1998).

In this step the effects of the failure mode are specified. Column two and three in Table 2 explain the potential failure effects in ERP implementation. The numbers one to ten should be selected by FMEA team in order to determine the severity of failure effects. The number one is referred to the low severity while the 10 number is related to the high severity of failure effect. In this research, potential failure effects comprise time exceed, cost increasing and customer and employee dissatisfaction.

\section{Step3- Potential Failure Causes Specification}

Potential failure causes are system design deficiencies that result in the failure mode in ERP implementation. This step is the most significant step in analysing ERP implementation. The lack of these factors might be the reasons of failure in ERP implementation. Occurrence is also the rating value corresponding to the estimation number of frequencies and/or cumulative number of failures which can cause to unsuccessful implementation of ERP. Numbers one to ten are allocated for the significance value of the factors. Column four and five as presented in Table 2 
explain the potential failure causes and occurrence value. In this study, (CFF as explained in Table1) are considered as potential failure causes in FMEA methodology.

\section{Step4- Control of Failure Modes}

This step includes the method that can be used for identifying and preventing the failure occurs in ERP implementation process. The number one is referred to the high probability of identification while the number 10 is related to the low probability of identifying the failure in ERP implementation. Columns six and seven in Table 2 explain the control and detection of failure in ERP implementation. In this paper, controls of failures include ERP system selection, organizing, planning, scheduling and training.

\section{Step5- Failure Mode Risk Prioritizing}

The last step of FMEA is prioritizing failure modes. In this step risk priority number (RPN) measure is used. This number is the product of severity, occurrence, and detection $(\mathrm{RPN}=\mathrm{S} \times \mathrm{O} \times \mathrm{D})$. The RPN defines the priority of the failure.

\section{Case Study}

The empirical study in this research is implemented in HamgamKhodro Company. This Company started its activity in the fields of mould manufacture, mass production of pressed parts of vehicle's body, and assembly of the sets in 2004. This company as a manufacture of varieties of moulds and vehicle body parts, located at an industrial town in Isfahan on a plot of $16000 \mathrm{~m}^{2}$ area. Owning over 80 various presses (heavy mechanical, gate, C-frame, progressive presses) with 100 to 800 tons capacities. This company is one of the greatest domestic private-sector press shop manufacturing pressed parts. The company has more than 400 personnel with various specialties and expertise. The company intends to implement ERP software for facilitating its business processes.

\section{Results}

Following the methodology of this research, unsuccessful implementation of ERP is considered as a potential failure mode in FMEA technique. Potential failure effect of ERP projects includes time exceed, cost increase and customer and employee dissatisfaction. An expert and specialist team which is acquainted with the structure and condition of organization assigned the numbers in Table 3-5. For example the severity number for time exceed is considered 8 in a 1 to 10 scale. The next step of FMEA is identification of potential failure causes. The potential failure causes which may lead to unsuccessful implementation of ERP are the critical failure factors in ERP implementation such as organization fit, ERP teamwork and skill mix, etc. The mentioned factors were presented in Table 1. Occurrence numbers are also assigned for all potential failure causes. For example - in Table 3- the highest number of occurrence "9" refers to project management and control while, the lowest number " 2 " is related to IT. In step 4, the company should emphasize on control activities which should be implemented for detecting and preventing failures in ERP implementation. Control activities considered in this research are ERP system selection, organizing, training, planning and scheduling. In the last step, RPN value should be calculated for each factor. RPN number is the product of severity, occurrence and detection values. It is clear that higher RPN number shows the higher risk in ERP project. Since potential failure effects cannot be improved easily in the presented model, in order to increase the success of ERP projects, focus on potential failure causes and control factors seems inevitable.

As shown in Table 3, the highest RPN numbers are 280, 256 and 216 respectively. Therefore, the first three priorities of risk can be identified. The occurrence number of "project management and control: equal to " 9 " also shows the sensitivity of this factor and its influence on the unsuccessful implementation of ERP projects which are related to time exceed. In general, RPN numbers imply that high organization fit, team work and project management and control can increase the possibility of success in implementing ERPs which are imposed by time exceed.

Table 4 also reveals that in order to decrease the amount of implementations caused by increase in cost, we need to improve top management support, organization fit and software system design, respectively as they have the highest RPNs. Since, the occurrence number of "financial support" is equal to "8", this factor should be also considered and improved in ERP implementation projects. Table 5 shows that two important factors in influencing the possibility of success in implementing ERPs which are imposed by customer and employee dissatisfaction. As shown in Table 5, the highest RPN numbers are 224, 210 and 175 respectively. Therefore, the first three priorities of risk can be identified. The occurrence numbers of "user involvement and control" and "teamwork": equal to "8" also show the sensitivity of this factor and its influence on the unsuccessful implementation of ERP projects which are related to customer and employee dissatisfaction. In general, RPN numbers imply that team work, software system design, organization fit and user involvement and control can increase the possibility of success in implementing ERPs.

\section{Discussion and Conclusions}

During the past decade, the huge investment in ERP system packages and the significant different adoption results has prompted many researchers to search for critical success factors. Therefore, implementation of ERP must be 
viewed as a transformation in which the company does business. The implementation of ERP contains various changes, which may cause conflicts in different departments. Without the intervention of senior management, no one will compromise the rearrangement of ERP. Some of the biggest ERP system implementation failures occur because new software capabilities and needs are mismatched with the organization's business process and procedures. The mismatch between ERP systems, existing structure, and business process of organization will generate widespread chaos.

In recent years, there has been an abundance of research on ERP. Many studies in the ERP literature have examined the issue of the adoption of ERP at a higher level. Some authors believe in-depth studies into the experience of the success (failure) of ERP for both advanced and developing regions/countries will be of great benefit to organizations. For instance, the literature has alluded to the proper management of consultants, and training as critical to the success of ERP projects. There have been many recent reports in the industrial literature about the managing of consultants and training as causes of ERP failures. Conversely, training is regarded as one of the critical resources of an organization that must be managed on an on-going basis. An in-depth study of existing cases would uncover the details of the 'what' and 'how' of ERP implementation.

The findings of this study are compatible with the study of Kim et al. (2005) and Koh et al. (2006) in which project management were identified as a critical factors. Crisostomo (2008) also believed that teamwork is a factor which can influence ERP successful implementation in public center.

This research presented a practical methodology for identifying the main reasons of failure in ERP implementation. Based on the review of relevant literatures and the result of this study, this research demonstrated the most critical elements affecting the implementation of ERP successfully. This methodology provided a suitable structure for determining the main causes of ERP projects failures are used. FMEA methodology for preventing failure in ERP implementation projects in order to prioritize and identify the significant factors of ERP failure. The proposed methodology is unique because it considers the intangible aspects of organizations which influence the ERP implementation successfully. This approach also considered all the management parts of a firm because these factors are available in all the organizations, however the importance of which may differ. Although previous researchers have identified the critical factors which may influence successful implementation of ERP, this study not only propose a method which can determine the factors affect ERP implementation, but also consider the relationship between potential failure causes and potential failure effects. For example organization fit, top management support and project management and control are the items which may lead to time exceed in ERP projects. This study recommends that organizations consider the intangible aspects of organization as an integrated management approach and also recognize the most important factors which may cause to failure in ERP implementation through FMEA technique. Thus, a good implementation of ERP requires considering the management aspects of organization. Based on the extensive survey and ERP literature, this study introduced 12 factors and 40 sub-factors which influence the implementation of ERP projects. The sub factors explain the details of each factor and help organization to determine how an organization can improve the critical factors in ERP implementation. This study is limited to one company and so it cannot be applicable to other organizations. Therefore, it is recommended that further researches comprise a more comprehensive case studies in order to adopt findings to other organizations.

\section{References}

Ahsen A.V. (2008). Cost-oriented failure mode and effects analysis.International Journal of Quality \& Reliability Management. 25(5), 466-476.

Al-Mashari, M. (2002), Enterprise resource planning (ERP) systems: a research agenda, Industrial Management \& Data Systems, 102(3), 165-170.

Aloini D. Dulmin R. \&Mininno V. (2007). Risk management in ERP project introduction: Review of the literature. Information and Management. 44(6), 547-567.

Barki, H. Rivard S. \& Talbot J. (1993).Toward an assessment of software development risks.Journal of Management information Systems. 10(2), 203-225.

Bingi P. Sharma M.K. and Godla J. (1999).Critical issues affecting an ERP implementation.Information Systems Management. 16(2), 7-14.

Chen I.J. (2001). Planning for ERP systems: analysis and future trend.Business Process Management Journal. 7(5), 374-386.

Crisostomo, D.T. (2008). Characteristics and skills of implementing an ERP system in the GUAM public sector, Journal of International Business Research, 7(1), 31-52. 
Davenport TH. (1998). Putting the enterprise into the enterprise system. Harvard Business Review.76(4), 121-31.

Huang S.M. Chang I.Ch. Li S.H. \& Lin M.T.(2004). Assessing risk in ERP projects: identify and prioritize the factors. Industrial Management \& Data Systems. 104(8), 681-688.

Kim, Y. Lee, Z. \&Gosain, S. (2005). Impediments to successful ERP implementation process, Business Process Management Journal, 11(2), 158-170

Koh, S.C.L, Simpson, M., Padmore, J., Dimitriadis, N. \&Misopoulos, F. (2006). An Exploratory Study of Enterprise Resource Planning Adoption in Greek Companies,Industrial Management \& data Systems, 106(7), 1033-1059.

Mahapatra, R.K \& Lai V.S. (1998). Intranet-based training facilitates on ERP system implementation: a case study in: E.D. Hoadley, I. Benbasat (Eds.). Proceedings of the Fourth Americas Conference on Information Systems, Baltimore.1070-1072.

Murray M. and Coffin G. (2001). A case study analysis of factors for success in ERP system implementations. Proceedings of the Seventh Americas Conference on Information Systems, Boston, 1012-1018.

Nah F.F.H. Zuckweiler K.M. \& Lau J.L.S. (2003). ERP Implementation: Chief Information Officers' Perceptions of Critical Success Factors. International Journal of Human-Computer Interaction. 16(1), 5-22.

Nelson RR. (1987). And Cheney PH. Training end users: an exploratory study. MIS Quarterly. 11(4), 547-559.

Ngai E.W.T. Law C.C.H. and Wat F.K.T. (2008). Examining the critical success factors in the adoption of enterprise resource planning. Computers in Industry. 59(6), 548-564.

Scheer A. \&Habermann F. (2000). Enterprise resource planning: Making ERP a success. Communications of the $A C M, 43(4), 57-61$.

Segismundo A. \& Miguel P.A.C. (2008). Failure mode and effects analysis (FMEA) in the context of risk management in new product development.International Journal of Quality \& Reliability Management. 25(9), 899-912.

Shanks G. Parr A. Hu B. Corbitt B. Thanasankit T. \&Seddon P. (2000). Differences in critical success factors in ERP systems implementation in Australia and China: A cultural analysis.Proceedings of the 8th European Conference on Information Systems, Vienna, Austria.537-544.

Sumner M. (1999). Critical success factors in enterprise wide information management systems projects. Proceedings of the Americas Conference on Information Systems. Milwaukee, WI; 232-234.

Umble E.J. Haft R.R. \&Umble M.M. (2003). Enterprise resource planning: implementation procedures and critical success factors. European Journal of Operational Research. 146(2), 241-257.

Wagner E.L. \& Newell S. (2006). Repairing ERP: producing social order to create a working information system.Journal of Applied Behavioral Science. 42(1), 40-57.

Wee S. (2000). Juggling toward ERP success: Keep key success factors high.ERP News. Retrieved June 1, 2000, availavle at: http://www.erpnews.com/erpnews/erp904/02get.html.

Zafiropoulos E.P. \&Dialynas E.N. (2005). Reliability prediction and failure mode effects and criticality analysis of electronic devices using fuzzy logic.International Journal of Quality \& Reliability Management. 22(2), 183-200. 
Table 1. Critical failure factors in ERP implementation (Aloini et al., 2007; Huang et al.,2004; Nah et al., 2003)

\begin{tabular}{|c|c|c|}
\hline \multirow{12}{*}{ 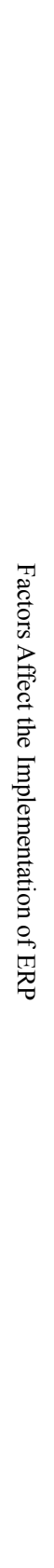 } & Organization Fit & $\begin{array}{l}\text { Insufficient resources } \\
\text { Extent of change } \\
\text { Failure to redesign business process } \\
\text { Fail to support cross-organization design }\end{array}$ \\
\hline & $\begin{array}{l}\text { ERP Teamwork } \\
\text { \& Skill Mix }\end{array}$ & $\begin{array}{l}\text { Fail to recruit \& retain ERP professional } \\
\text { Lack of appropriate experience of the user representatives } \\
\text { The ability \& experience of inner expertise } \\
\text { Inappropriate Staffing } \\
\text { Lack of analyst with business and technology knowledge } \\
\text { Failure to mix internal and external expertise effectively }\end{array}$ \\
\hline & $\begin{array}{l}\text { Project Management } \\
\quad \& \text { Control }\end{array}$ & $\begin{array}{l}\text { Lack of agreement on project goals and scope } \\
\text { Lack of senior management commitment to project } \\
\text { The composition of project team members } \\
\text { Lack of effective project management methodology }\end{array}$ \\
\hline & Software System Design & $\begin{array}{l}\text { Unclear/Misunderstand changing requirements } \\
\text { Lack of effective software management methodology } \\
\text { Unable to comply with the standard which ERP software supports } \\
\text { Lack of integration between enterprise-wide systems } \\
\text { Developing the wrong functions and wrong user interface }\end{array}$ \\
\hline & $\begin{array}{l}\text { User Involvement } \\
\text { and Training }\end{array}$ & $\begin{array}{l}\text { Conflicts between user departments } \\
\text { Fail to get user support } \\
\text { Low key user involvement } \\
\text { Inadequate training \& instruction }\end{array}$ \\
\hline & Technology Planning & $\begin{array}{l}\text { Capability of current enterprise technical infrastructure } \\
\text { Technology newness } \\
\text { Stability of current technology } \\
\text { Attempting to link legacy systems }\end{array}$ \\
\hline & Communication & $\begin{array}{l}\text { Inefficient communication } \\
\text { Expectations communicated at all levels }\end{array}$ \\
\hline & $\begin{array}{c}\text { Information } \\
\text { Technology \& Legacy System }\end{array}$ & $\begin{array}{l}\text { Inadequate IT system issue } \\
\text { Inadequate IT system maintainability } \\
\text { Inadequate IT supplier stability and performances } \\
\text { Inappropriate legacy system and business setting } \\
\end{array}$ \\
\hline & Change Management & Inadequate change management \\
\hline & BPR & Inadequate BPR \\
\hline & Top Management Support & $\begin{array}{l}\text { Bad management contact } \\
\text { Low top management involvement } \\
\text { Poor leadership } \\
\text { Ineffective strategic thinking \& planning }\end{array}$ \\
\hline & Financial Support & Inadequate financial management \\
\hline
\end{tabular}

Table 2. An example sample for the application of FMEA in ERP implementation

\begin{tabular}{|c|c|c|c|c|c|c|c|}
\hline $\begin{array}{c}\text { (1) } \\
\text { Potential Failure } \\
\text { Mode } \\
\end{array}$ & $\begin{array}{c}\text { (2) } \\
\text { Potential Failure Effect }\end{array}$ & $\begin{array}{c}\text { (3) } \\
\text { Severity }\end{array}$ & $\begin{array}{c}(4) \\
\text { Potential Failure } \\
\text { Causes } \\
\end{array}$ & $\begin{array}{c}\text { (5) } \\
\text { Occurrence }\end{array}$ & $\begin{array}{c}(6) \\
\text { Control }\end{array}$ & $\begin{array}{c}(7) \\
\text { Detection }\end{array}$ & $\begin{array}{l}(8) \\
\text { RPN }\end{array}$ \\
\hline \multirow{5}{*}{ 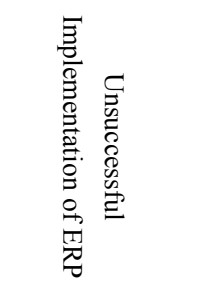 } & \multirow[t]{2}{*}{ Time exceed } & \multirow[t]{2}{*}{8} & \multirow[t]{2}{*}{ Organization Fit } & \multirow[t]{2}{*}{7} & $\begin{array}{l}\text { ERP system } \\
\text { selection }\end{array}$ & 5 & 280 \\
\hline & & & & & Organizing & 2 & 112 \\
\hline & \multicolumn{7}{|c|}{$\begin{array}{lll} & \cdot & \cdot \\
\end{array}$} \\
\hline & \multirow{2}{*}{$\begin{array}{l}\text { Customer \& Employee } \\
\text { Dissatisfaction }\end{array}$} & \multirow[t]{2}{*}{7} & \multirow{2}{*}{$\begin{array}{c}\text { Software system } \\
\text { design }\end{array}$} & \multirow[t]{2}{*}{6} & $\begin{array}{l}\text { ERP system } \\
\text { selection }\end{array}$ & 5 & 210 \\
\hline & & & & & Planning & 3 & 126 \\
\hline
\end{tabular}


Table 3. Potential failure effect in ERP implementation- Time exceed

\begin{tabular}{|c|c|c|c|c|c|c|c|}
\hline $\begin{array}{c}\text { Potential Failure } \\
\text { Mode }\end{array}$ & $\begin{array}{c}\text { Potential Failure } \\
\text { Effect }\end{array}$ & Severity & Potential Failure Causes & Occurrence & Control & Detection & RPN \\
\hline \multirow{17}{*}{ 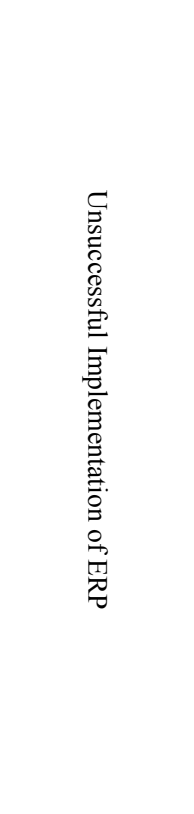 } & \multirow{17}{*}{ 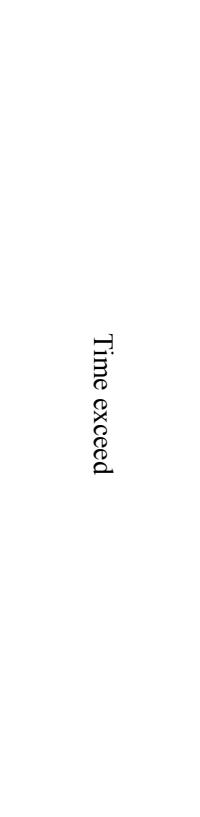 } & \multirow{17}{*}{8} & \multirow[t]{2}{*}{ Organization Fit } & \multirow[t]{2}{*}{7} & $\begin{array}{l}\text { ERP system } \\
\text { selection }\end{array}$ & 5 & 280 \\
\hline & & & & & Organizing & 2 & 112 \\
\hline & & & Team work & 5 & Training & 4 & 160 \\
\hline & & & \multirow{2}{*}{ Top management support } & \multirow{2}{*}{8} & Training & 4 & 256 \\
\hline & & & & & Organizing & 2 & 128 \\
\hline & & & \multirow{2}{*}{ Financial support } & \multirow{2}{*}{4} & Planning & 3 & 96 \\
\hline & & & & & Scheduling & 3 & 96 \\
\hline & & & \multirow{2}{*}{$\begin{array}{c}\text { Project management \& } \\
\text { control }\end{array}$} & \multirow{2}{*}{9} & Planning & 3 & 216 \\
\hline & & & & & Scheduling & 3 & 216 \\
\hline & & & \multirow{2}{*}{$\begin{array}{c}\text { User Involvement \& } \\
\text { training }\end{array}$} & \multirow{2}{*}{6} & Planning & 3 & 114 \\
\hline & & & & & Organizing & 2 & 96 \\
\hline & & & \multirow[t]{2}{*}{ Software system design } & \multirow[t]{2}{*}{3} & $\begin{array}{l}\text { ERP system } \\
\text { selection }\end{array}$ & 5 & 120 \\
\hline & & & & & Planning & 3 & 72 \\
\hline & & & Change management & 4 & Training & 4 & 128 \\
\hline & & & IT & 2 & Training & 4 & 64 \\
\hline & & & \multirow{2}{*}{ Communication } & \multirow{2}{*}{5} & Training & 4 & 160 \\
\hline & & & & & Planning & 3 & 120 \\
\hline
\end{tabular}

Table 4. Potential failure effect in ERP implementation- Cost increasing

\begin{tabular}{|c|c|c|c|c|c|c|c|}
\hline $\begin{array}{c}\text { Potential Failure } \\
\text { Mode }\end{array}$ & $\begin{array}{c}\text { Potential Failure } \\
\text { Effect }\end{array}$ & Severity & Potential Failure Causes & Occurrence & Control & Detection & RPN \\
\hline \multirow{17}{*}{ 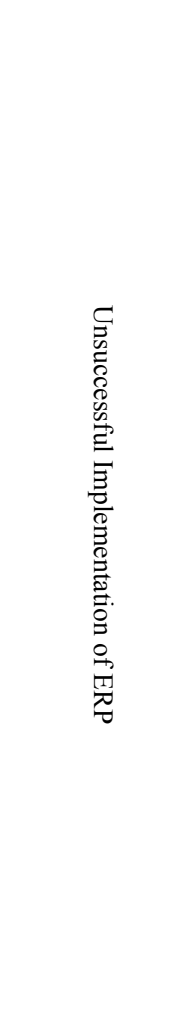 } & \multirow{17}{*}{ 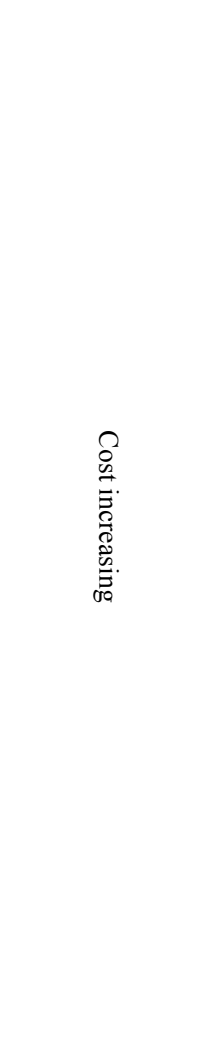 } & \multirow{17}{*}{5} & \multirow[t]{2}{*}{ Organization Fit } & \multirow[t]{2}{*}{5} & $\begin{array}{c}\text { ERP system } \\
\text { selection }\end{array}$ & 5 & 125 \\
\hline & & & & & Organizing & 2 & 50 \\
\hline & & & Team work & 5 & Training & 4 & 100 \\
\hline & & & \multirow{2}{*}{ Top management support } & \multirow{2}{*}{7} & Training & 4 & 140 \\
\hline & & & & & Organizing & 2 & 70 \\
\hline & & & \multirow{2}{*}{ Financial support } & \multirow{2}{*}{8} & Planning & 3 & 120 \\
\hline & & & & & Scheduling & 3 & 120 \\
\hline & & & \multirow{2}{*}{$\begin{array}{c}\text { Project management \& } \\
\text { control }\end{array}$} & \multirow{2}{*}{4} & Planning & 3 & 60 \\
\hline & & & & & Scheduling & 3 & 60 \\
\hline & & & \multirow{2}{*}{$\begin{array}{c}\text { User Involvement \& } \\
\text { training }\end{array}$} & \multirow{2}{*}{3} & Planning & 3 & 45 \\
\hline & & & & & Organizing & 2 & 30 \\
\hline & & & \multirow[t]{2}{*}{ Software system design } & \multirow[t]{2}{*}{5} & $\begin{array}{c}\text { ERP system } \\
\text { selection }\end{array}$ & 5 & 125 \\
\hline & & & & & Planning & 3 & 75 \\
\hline & & & Change management & 4 & Training & 4 & 80 \\
\hline & & & IT & 4 & Training & 4 & 80 \\
\hline & & & \multirow{2}{*}{ Communication } & \multirow{2}{*}{6} & Training & 4 & 120 \\
\hline & & & & & Planning & 3 & 90 \\
\hline
\end{tabular}


Table 5. Potential failure effect in ERP implementation- Customer \& employee

\begin{tabular}{|c|c|c|c|c|c|c|c|}
\hline $\begin{array}{c}\text { Potential Failure } \\
\text { Mode }\end{array}$ & $\begin{array}{c}\text { Potential Failure } \\
\text { Effect }\end{array}$ & Severity & Potential Failure Causes & Occurrence & Control & Detection & RPN \\
\hline \multirow{17}{*}{ 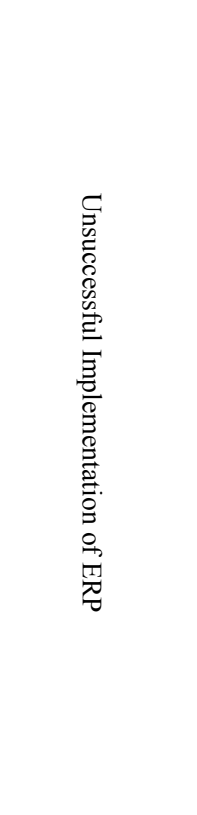 } & \multirow{17}{*}{ 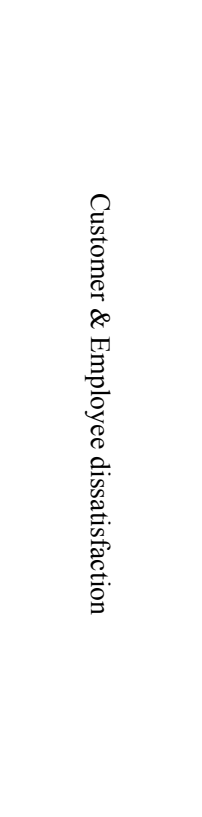 } & \multirow{17}{*}{7} & \multirow[t]{2}{*}{ Organization Fit } & \multirow[t]{2}{*}{5} & $\begin{array}{l}\text { ERP system } \\
\text { selection }\end{array}$ & 5 & 175 \\
\hline & & & & & Organizing & 2 & 70 \\
\hline & & & Team work & 8 & Training & 4 & 224 \\
\hline & & & \multirow{2}{*}{ Top management support } & \multirow{2}{*}{5} & Training & 4 & 140 \\
\hline & & & & & Organizing & 2 & 70 \\
\hline & & & \multirow{2}{*}{ Financial support } & \multirow{2}{*}{4} & Planning & 3 & 84 \\
\hline & & & & & Scheduling & 3 & 84 \\
\hline & & & \multirow{2}{*}{$\begin{array}{l}\text { Project management \& } \\
\text { control }\end{array}$} & \multirow{2}{*}{7} & Planning & 3 & 147 \\
\hline & & & & & Scheduling & 3 & 147 \\
\hline & & & \multirow{2}{*}{$\begin{array}{c}\text { User Involvement \& } \\
\text { training } \\
\end{array}$} & \multirow{2}{*}{8} & Planning & 3 & 168 \\
\hline & & & & & Organizing & 2 & 112 \\
\hline & & & \multirow[t]{2}{*}{ Software system design } & \multirow[t]{2}{*}{6} & $\begin{array}{c}\text { ERP system } \\
\text { selection }\end{array}$ & 5 & 210 \\
\hline & & & & & Planning & 3 & 126 \\
\hline & & & Change management & 3 & Training & 4 & 84 \\
\hline & & & IT & 6 & Training & 4 & 168 \\
\hline & & & \multirow{2}{*}{ Communication } & \multirow{2}{*}{5} & Training & 4 & 140 \\
\hline & & & & & Planning & 3 & 105 \\
\hline
\end{tabular}

